\title{
Evaluation of potential of selected prebiotics on probiotic $L$. acidophilus and L. casei strains
}

\author{
H. C. Devaraja ${ }^{1 *}$, H. M. Jayaprakasha ${ }^{2}$ and K. Jayaraj Rao ${ }^{3}$
}

\begin{abstract}
${ }^{1}$ Dairy Technology section, ICAR-National Dairy Research Institute, Adugodi, Bengaluru - 560 030, Karnataka, India; ${ }^{2}$ Dairy Science College, Department of Dairy Technology, Hebbal-560 024 KVAFSU, Bidar, India; ${ }^{3}$ Dairy Technology section, ICAR-National Dairy Research Institute, Adugodi, Bengaluru - 560 030, Karnataka, India
\end{abstract}

\begin{abstract}
Attempts were made to understand the fermentation kinetics of fructo-oligosaccharides (FOS), inulin and isomaltooligosaccharides (IMO) supplemented skim milk samples and its effect on direct microscopic clump (DMC) count of L. acidophilus and $L$. casei strains in skim milk medium. It was found that supplementation of FOS at $2 \%$ level significantly $(\mathbf{p}<0.05)$ increased the rate of acidification by $21.43 \%$ and $17.74 \%$ in $L$. acidophilus and $L$. casei inoculated sample compared to control, respectively. Skim milk supplemented with $3 \%$ FOS and inoculated with $4 \%$ L. casei culture recorded highest DMC count $\left(9.28 \log _{10} \mathrm{cfu} / \mathrm{g}\right)$ followed by IMO $\left(9.20 \log _{10} \mathrm{cfu} / \mathrm{g}\right)$ and Inulin $\left(9.16 \log _{10} \mathrm{cfu} / \mathrm{g}\right)$ supplemented sample inoculated with $L$. casei.
\end{abstract}

Key words: Fructo-oligosaccharides, Inulin, Isomalto-oligosaccharides, Lactobacillus acidophilus, Lactobacillus casei

\section{Highlights}

- Addition of prebiotics viz. FOS, inulin and IMO increased the rate of acidification and DMC count.

- L. acidophilus performed better compared to L. casei in terms of acid production.

- Addition of FOS at the rate of 3 per cent recorded the highest mean DMC count of $8.84 \log _{10}$ cells/g.

- L. casei added at the rate of $5 \%$ recorded significantly $(\mathrm{p}<0.05)$ higher DMC count.

\section{INTRODUCTION}

Oligosaccharides are short chain carbohydrates, having two to ten monosaccharides units linked together with glycosidic bonds. Some of the oligosaccharides, known as functional oligosaccharides, are resistant to digestion by human gut enzymes and selectively fermented by specific genera/species of resident gut microbes resulting in targeted increase in specific bacterial population that confers health benefits to the host (Roberfroid et al., 2010). The common known functional oligosaccharides are fructo-oligosaccharides, galacto-oligosaccharides, malto-oligosaccharides, isomalto-oligosaccharides etc. (Ibrahim, 2018).
Inulin, a mixture of oligo- and polysaccharides, is composed of fructose moieties joined by $\beta$ $(2->1)$ linkages in linear chains. The above oligosaccharides and inulin exhibit excellent prebiotic potential, which promotes the growth of probiotic bacterial strains (Oliveira et al., 2013; Canbulat and Ozcan, 2015). The application of oligosaccharides as a prebiotic ingredient in dairy products and other foods such as breakfast cereal and soft drinks is increasing exponentially.

In recent times, probiotic food and beverages segment is attracting more popularity in urban population due to growing health and diet 
consciousness among the consumer group. Probiotic food is defined as a processed product which contains viable probiotic microorganisms in a suitable matrix and in sufficient concentration (Parvez et al., 2006). Probiotic bacteria have been recommended for the treatment of atopic dermatitis, chronic liver disease, allergic disease, necrotizing enterocolitis, pseudo-membranous colitis and food allergy (Salminen et al., 2005). Dairy foods are one of the most versatile food segments, appealing to many palates and suitable for all age groups, and also offers versatile opportunities as a probiotic food carrier (Shah, 2007). Among the probiotics, L. acidophilus and L. casei had been studied extensively for their growth kinetics in milk medium and their contribution to gut health in humans.

\section{MATERIALS AND METHODS}

Oligosaccharides such as FOS (FOSSENCE ${ }^{\mathrm{TM}}$ ) and IMO (VitaFibre ${ }^{\mathrm{TM}}$ ) as well as inulin (Frutafit ${ }^{\circledR}$ HD) were procured from Tata Chemicals Ltd, India; Sensus, Netherlands and Bioneutra Inc., North America, respectively. Freeze-dried DVS probiotic strains of Lactobacillus acidophilus (La-5) and Lactobacillus casei (L. casei 431®) were obtained from Chr. Hansen Lab. (Hoersholm, Denmark) as free samples. Milk was collected from the dairy farm of ICAR-National Dairy Research Institute, Bengaluru and was standardised to $<0.5 \%$ fat and $8.7 \%$ SNF for use as growth medium.

\footnotetext{
Supplementation of skim milk with selected prebiotics: The milk standardised to $<0.5 \%$ fat and $8.7 \%$ SNF was thermally processed to $90^{\circ} \mathrm{C}$ for $10 \mathrm{~min}$. The selected prebiotics were added at the rate of $2 \%$ to the processed skim milk. The probiotic culture was added at the rate of $4 \%$ and incubated at $40 \pm 2^{\circ} \mathrm{C}$. The samples were analysed for $\mathrm{pH}$ and acidity at every two hours interval. The $\mathrm{pH}$ of the samples was measured using a $\mathrm{pH}$ meter (Labindia, India) and the titratable acidity in terms of \% lactic acid was determined using the method described by AOAC (1995). The change in $\mathrm{pH}$ during
}

fermentation was monitored at every $2 \mathrm{~h}$ intervals upto $6 \mathrm{~h}$ and final acidification rate $\left(\mathrm{V}_{\mathrm{f}}\right)$ was calculated as the time variation of $\mathrm{pH}$ using formula $(\mathrm{dpH} / \mathrm{dt})$ and expressed $i n 10^{-3} \mathrm{pH}$ units/min.

\section{Enumeration of direct microscopic clump count} (DMCC): The DMC count was enumerated using the method described by Harrigan (1998). The well mixed samples were diluted to $1: 10$ using sterile physiological saline as diluent. Sample of $0.01 \mathrm{~mL}(10 \mu \mathrm{L})$ was transferred using a micropipette onto a marked slide of $1 \mathrm{~cm}^{2}$ and smear was prepared by spreading evenly on the marked area. The smear was fixed using ethanol for $2 \mathrm{~min}$ and stained using borax methylene blue for $5 \mathrm{~min}$ and then rinsed with tap water. After air drying, the smear was observed under the oil immersion objective and organisms were counted in each of the field. The average number of organisms per field was calculated and multiplied by microscopic factor, dilution factor and 100. The DMC count was expressed as $\log _{10}$ cells per gram of the sample.

\section{RESULTS}

Effect of selected prebioticson pH of milk: As depicted in Fig. 1A, skim milk supplemented with selected prebiotics recorded significantly lower $\mathrm{pH}$ compared to control, upon incubation for $6 \mathrm{~h}$ with probiotic L. acidophilus and L. casei strains, inoculated at $4 \%$ level. The skim milk sample supplemented with $2 \%$ FOS, recorded very low $\mathrm{pH}$ of 4.35 compared to inulin (4.55) and IMO (4.56) supplemented samples. It is clear from Table 1 that the sample supplemented with FOS and inoculated with L. acidophilus recorded significantly $(\mathrm{p}<0.05)$ higher acidification rate of $6.139 \times 10^{-3} \mathrm{pH}$ units $\min ^{-1}$ and $21.43 \%$ more compared to control $\left(5.056 \times 10^{-3} \mathrm{pH}\right.$ units $\left.\mathrm{min}^{-1}\right)$, followed by inulin $\left(5.667 \times 10^{-3} \mathrm{pH}\right.$ units

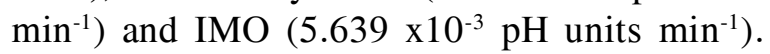
The $\beta$ co-efficient of regression equations presented in Table 2 indicates that the interaction of FOS with $L$. acidophilus reduced the $\mathrm{pH}$ of milk at a faster rate compared to all other combinations. 
Effect of selected prebiotics on acidity of milk: The skim milk samples inoculated with L.acidophilus and added with selected prebiotics recorded significant $(\mathrm{p}<0.05)$ rise in acidity from 0.18 to $0.77 \%$ LA over $6 \mathrm{~h}$ of incubation (Fig. 1B). The control skim milk sample recorded the lowest acidity $(0.51 \% \mathrm{LA})$ while the milk added with FOS recorded significantly $(\mathrm{p}<0.05)$ higher $(0.77 \% \mathrm{LA})$ rise in acidity after $6 \mathrm{~h}$ of incubation at $40 \pm 2^{\circ} \mathrm{C}$ followed by IMO $(0.69 \% \mathrm{LA})$ and inulin $(0.68 \%$ LA). The skim milk samples without addition of prebiotics recorded lowest acidity of 0.57 and $0.51 \%$ LA when inoculated with $L$. acidophilus and $L$. casei, respectively. The acidity of milk, inoculated with $L$. casei was more influenced by FOS and thus the milk sample with FOS and L. casei combination recorded the highest acidity of $0.65 \% \mathrm{LA}$ as compared to $L$. casei with inulin $(0.60 \%$ LA) and IMO $(0.63 \%$ LA) combinations. However, the magnitude of $\beta$ co-efficient of regression equations clearly depicts that the interaction of FOS with $L$. casei increased the acidity of skim milk at a faster rate compared to all other combinations (Table 2).
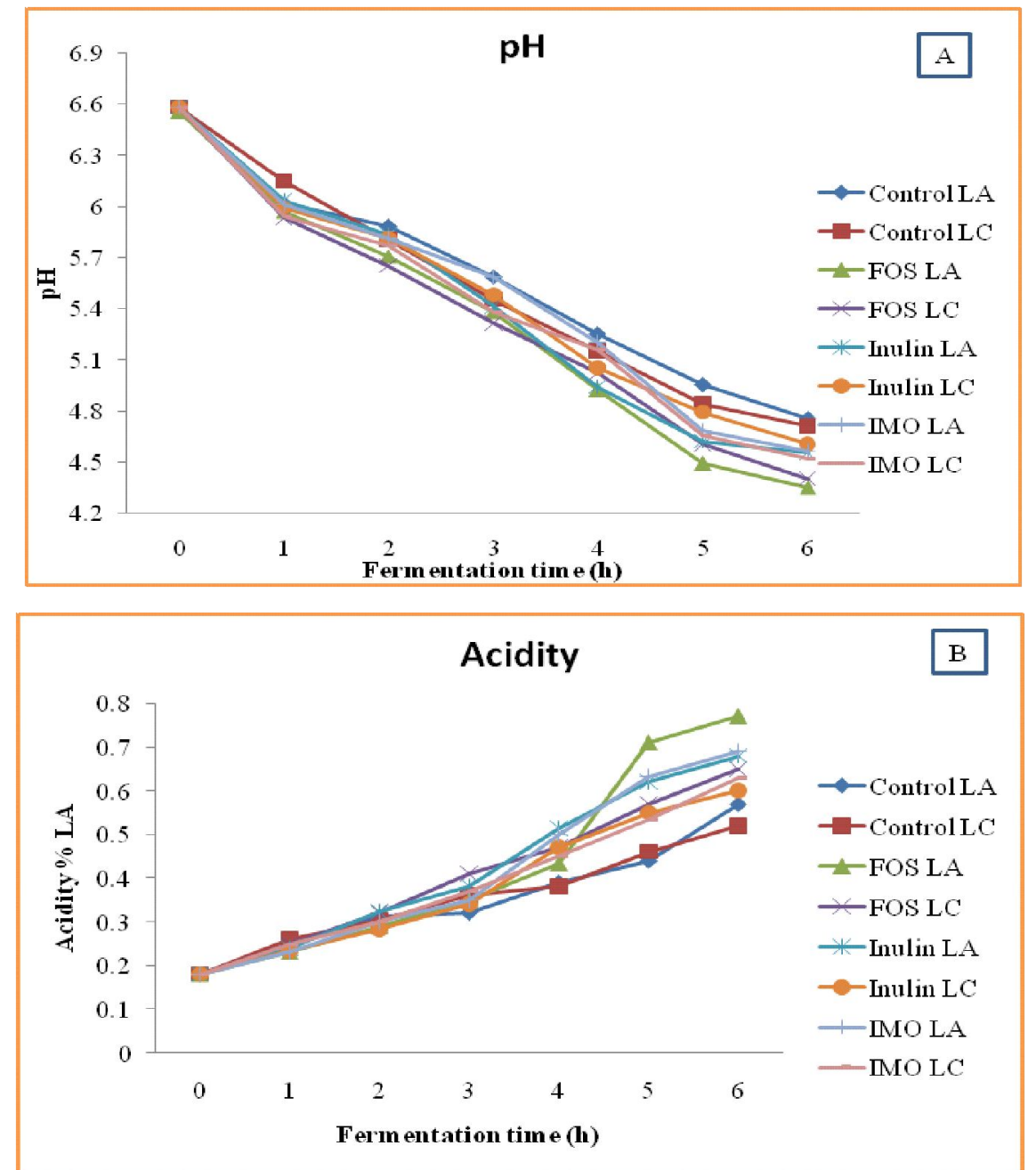

FOS: Fructo-oligosaccharides, IMO: Isomalto-oligosaccharides, LA: Lactobacillus acidophilus, LC: Lactobacillus casei

Fig. 1. Effect of selected prebiotics on pH (A) and acidity (B) of skim milk inoculated with L. acidophilus and L. casei 
Table 1. Mathematical model adjusted to the experimental data of pH and acidity with model parameters and coefficient of determination (Adj $\left.R^{2}\right)$

\begin{tabular}{|c|c|c|c|c|c|}
\hline Parameter & $\begin{array}{c}\text { Probiotic } \\
\text { culture }\end{array}$ & Prebiotics & Model equation & $\operatorname{Adj} R^{2}$ & F value \\
\hline \multirow{5}{*}{$\mathrm{pH}$} & \multirow{4}{*}{ L. acidophilus } & Control & $y=-0.295 x+6.752$ & 0.98 & $845.19 * *$ \\
\hline & & FOS & $\mathrm{y}=-0.370 \mathrm{x}+6.82$ & 0.98 & $1306.72 * *$ \\
\hline & & Inulin & $y=-0.35 x+6.823$ & 0.91 & $213.16 * *$ \\
\hline & & IMO & $y=-0.333 x+6.821$ & 0.96 & $445.41 * *$ \\
\hline & \multirow{4}{*}{ L. casei } & Control & $y=-0.317 x+6.792$ & 0.97 & $758.57 * *$ \\
\hline \multirow{11}{*}{ Acidity } & & FOS & $y=-0.351 x+6.76$ & 0.98 & $996.35 * *$ \\
\hline & & Inulin & $y=-0.325 x+6.771$ & 0.98 & $886.40 * *$ \\
\hline & & IMO & $y=-0.334 x+6.767$ & 0.96 & $474.76 * *$ \\
\hline & \multirow{4}{*}{ L. acidophilus } & Control & $\mathrm{y}=0.058 \mathrm{x}+0.119$ & 0.94 & $309.24 * *$ \\
\hline & & FOS & $y=0.014 x^{2}-0.014 x+0.19$ & 0.92 & $230.02 * *$ \\
\hline & & Inulin & $\mathrm{y}=0.087 \mathrm{x}+0.069$ & 0.97 & $774.84 * *$ \\
\hline & & IMO & $y=0.0065 x^{2}+0.0382 x+0.1281$ & 0.96 & $505.88 * *$ \\
\hline & \multirow{4}{*}{ L. casei } & Control & $\mathrm{y}=0.053 \mathrm{x}+0.138$ & 0.97 & $658.71 * *$ \\
\hline & & FOS & $\mathrm{y}=0.078 \mathrm{x}+0.092$ & 0.99 & $1574.66 * *$ \\
\hline & & Inulin & $\mathrm{y}=0.074 \mathrm{x}+0.082$ & 0.97 & $566.30 * *$ \\
\hline & & $\overline{\mathrm{IMO}}$ & $y=0.073 x+0.092$ & 0.98 & $928.74 * *$ \\
\hline
\end{tabular}

FOS: Fructo-oligosaccharides, IMO: Isomalto-oligosaccharides

Table 2. Effect of selected prebiotics on acidification rate

\begin{tabular}{|c|c|c|c|c|}
\hline \multirow[b]{2}{*}{ Substrate } & \multirow[b]{2}{*}{$\begin{array}{c}\text { Acidification rate } \\
\left(\mathrm{V}_{\mathrm{f}}\right)\left(\mathbf{1 0}^{-3} \mathrm{pH}\right. \\
\text { units } / \mathrm{min})\end{array}$} & \multicolumn{2}{|c|}{ L. acidophilus (4\%) } & casei $(4 \%)$ \\
\hline & & $\%$ Increase & $\begin{array}{c}\text { Acidification rate } \\
\left(\mathrm{V}_{\mathrm{f}}\right)\left(10^{-3} \mathrm{pH}\right. \\
\text { units } / \mathrm{min})\end{array}$ & $\%$ Increase \\
\hline Control & $5.056 \pm 0.01^{\mathrm{a}}$ & - & $5.167 \pm 0.02^{\mathrm{a}}$ & - \\
\hline $2 \% \mathrm{FOS}$ & $6.139 \pm 0.01^{b}$ & $21.43^{\mathrm{a}}$ & $6.083 \pm 0.02^{b}$ & $17.74^{\mathrm{a}}$ \\
\hline $2 \%$ Inulin & $5.667 \pm 0.02^{\mathrm{c}}$ & $12.09^{\mathrm{b}}$ & $5.444 \pm 0.02^{\mathrm{c}}$ & $5.38^{\mathrm{b}}$ \\
\hline $2 \% \mathrm{IMO}$ & $5.639 \pm 0.02^{\mathrm{c}}$ & $11.54^{\mathrm{c}}$ & $5.722 \pm 0.01^{\mathrm{d}}$ & $10.75^{\mathrm{c}}$ \\
\hline
\end{tabular}

$* \mathrm{n}=3$; Mean \pm SE; Values with different superscript letters within a column are significantly $(\mathrm{p}<0.05)$ different; FOS: Fructo-oligosaccharides, IMO: Isomalto-oligosaccharides

Effect of selected prebiotics on direct microscopic clump count (log ${ }_{10}$ cells/g) of L. acidophilus and L. casei: The skim milk sample standardised to $<0.5 \%$ fat and $8.7 \% \mathrm{SNF}$ was filled into $10 \mathrm{~mL}$ test tubes and selected prebiotic was added at $1 \%, 2 \%$ and $3 \%$ levels and sterilised at $120^{\circ} \mathrm{C} / 15 \mathrm{~min}$. After cooling to $40^{\circ} \mathrm{C}, \mathrm{L}$. acidophilus and $L$. casei at $3 \%, 4 \%$ and $5 \%$ levels were added in different combinations with prebiotics and incubated at $40 \pm 2^{\circ} \mathrm{C}$ for $8 \mathrm{~h}$. The direct microscopic clump count was enumerated by pour plate method.

Effect of fructo-oligosaccharides (FOS): Table 3 illustrates that, the rate of addition of FOS and probiotic strains, individually and in combination significantly $(\mathrm{p}<0.05)$ influenced the DMC count of the fermented skim milk. The 
Table 3. Effect of fructo-oligosaccharides on direct microscopic clumpcount (log 10 cells/g) of L. acidophilus and $L$. casei

\begin{tabular}{|c|c|c|c|c|c|c|}
\hline \multirow{3}{*}{\multicolumn{2}{|c|}{$\%$ Culture addition }} & \multirow{2}{*}{\multicolumn{3}{|c|}{$\frac{\text { Direct microscopic clump count }\left(\log _{10} \mathrm{cfu} / \mathrm{g}\right)}{\text { Fructo-oligosaccharides }}$}} & \multirow{3}{*}{$\begin{array}{l}\text { Statistical } \\
\text { mean }\end{array}$} & \multirow{3}{*}{$\begin{array}{l}\text { Statistical } \\
\text { mean }\end{array}$} \\
\hline & & & & & & \\
\hline & & $1 \%$ & $2 \%$ & $3 \%$ & & \\
\hline \multirow{3}{*}{ L. acidophilus } & 3 & $8.00 \pm 0.01^{\mathrm{aA}}$ & $8.20 \pm 0.04^{\mathrm{aA}}$ & $8.35 \pm 0.03^{\mathrm{aA}}$ & $8.21 \pm 0.15^{\mathrm{a}}$ & \multirow{3}{*}{$8.33 \pm 0.15^{\mathrm{a}}$} \\
\hline & 4 & $8.25 \pm 0.05^{\mathrm{abA}}$ & $8.34 \pm 0.05^{\mathrm{aA}}$ & $8.47 \pm 0.01^{\mathrm{aA}}$ & $8.35 \pm 0.10^{\mathrm{b}}$ & \\
\hline & 5 & $8.41 \pm 0.02^{\mathrm{bA}}$ & $8.48 \pm 0.03^{\mathrm{aA}}$ & $8.51 \pm 0.05^{\mathrm{aA}}$ & $8.47 \pm 0.05^{\mathrm{c}}$ & \\
\hline \multirow{3}{*}{ L. casei } & 3 & $8.79 \pm 0.03^{\mathrm{cA}}$ & $9.16 \pm 0.03^{\mathrm{bB}}$ & $9.20 \pm 0.04^{\text {bB }}$ & $9.05 \pm 0.20^{\mathrm{d}}$ & \multirow{3}{*}{$9.10 \pm 0.20^{\mathrm{b}}$} \\
\hline & 4 & $8.85 \pm 0.05^{\mathrm{cA}}$ & $9.26 \pm 0.03^{\mathrm{bB}}$ & $9.28 \pm 0.02^{\mathrm{bB}}$ & $9.13 \pm 0.21^{\mathrm{e}}$ & \\
\hline & 5 & $8.88 \pm 0.04^{\mathrm{cA}}$ & $9.26 \pm 0.02^{\mathrm{bB}}$ & $9.29 \pm 0.03^{\mathrm{bB}}$ & $9.14 \pm 0.19^{\mathrm{e}}$ & \\
\hline Statistical mean & & $8.53 \pm 0.34^{\mathrm{A}}$ & $8.78 \pm 0.46^{\mathrm{B}}$ & $8.84 \pm 0.42^{\mathrm{B}}$ & & \\
\hline
\end{tabular}

* $\mathrm{n}=3$; Mean \pm SE; Values with different superscript with small letters within a column are significantly $(\mathrm{p}<0.05)$ different; Values with different superscript with capital letters within a row are significantly $(\mathrm{p}<0.05)$ different

skim milk sample added with $1 \%$ FOS recorded significantly $(\mathrm{p}<0.05)$ lower $\left(8.53 \log _{10} \mathrm{cfu} / \mathrm{mL}\right)$ DMC count compared to that of the samples added with $2 \%\left(8.78 \log _{10} \mathrm{cfu} / \mathrm{mL}\right)$ and $3 \%(8.84$ $\log _{10} \mathrm{cfu} / \mathrm{mL}$ ) of FOS. However, there was nonsignificant difference between DMC count of samples added with FOS at 2 and 3\% levels. The mean DMC count of the samples inoculated with L. acidophilus differed significantly $(\mathrm{p}<0.05)$ at all the three levels of addition i.e. $3 \%, 4 \%$ and $5 \%$, which recorded $8.21 \log _{10} \mathrm{cfu} /$ $\mathrm{mL}, 8.35 \log _{10} \mathrm{cfu} / \mathrm{mL}$ and $8.47 \log _{10} \mathrm{cfu} / \mathrm{mL}$, respectively.

The skim milk sample inoculated with L. casei at 3\% level exhibited significantly $(\mathrm{p}<0.05)$ lower mean DMC count of 9.05 $\log _{10} \mathrm{cfu} / \mathrm{mL}$ compared to the samples added with $4 \%\left(9.13 \log _{10} \mathrm{cfu} / \mathrm{mL}\right)$ and $5 \%\left(9.14 \log _{10}\right.$ $\mathrm{cfu} / \mathrm{mL}$ ) of $L$. casei culture. However, there was no significant difference between DMC count of samples added with L. casei at 4 and 5\% levels. It is also clear from the Table 3 that L. casei inoculated samples recorded significantly $(\mathrm{p}<0.05)$ higher overall mean DMC count $\left(9.10 \log _{10} \mathrm{cfu} / \mathrm{g}\right.$ ) compared to that of $L$. acidophilus $\left(8.33 \log _{10} \mathrm{cfu} / \mathrm{g}\right)$.

Effect of inulin: Increasing the level of inulin significantly $(\mathrm{p}<0.05)$ increased the DMC count of the fermented skim milk. Inulin added at the rate of 1,2 and $3 \%$ recorded the mean DMC count of $8.28 \log _{10}$ cells/g, $8.55 \log _{10}$ cells/g and $8.67 \log _{10}$ cells/g, respectively (Table 4 ). Similarly, the DMC count of L. acidophilus and $L$. casei, added individually at different levels exhibited significant $(\mathrm{p}<0.05)$ differences within and between the cultures. The DMC count of the sample inoculated with L. acidophilus differed significantly $(\mathrm{p}<0.05)$ at all the three levels of addition i.e. 3, 4 and $5 \%$, which recorded the mean DMC count of $7.81 \log _{10}$ cells/g, $8.05 \log _{10}$ cells/g and $8.30 \log _{10}$ cells/g, respectively.

The skim milk sample inoculated with $L$. casei at $3 \%$ level exhibited significantly $(\mathrm{p}<0.05 \%)$ lower mean DMC count of $8.89 \log _{10}$ cells/g as compared to the samples added with $4 \%$ (8.97 $\log _{10}$ cells/g) and $5 \%\left(9.00 \log _{10}\right.$ cells/g) of the said culture. It is also clear from Table 4 that, the skim milk sample inoculated with L.casei recorded nearly one log higher mean DMC count (8.95 $\log _{10}$ cells/g) as compared to that of $L$. acidophilus (8.04 $\log _{10}$ cells/g).

Effect of isomalto-oligosaccharides (IMO): The IMO added at the rate of 1,2 and $3 \%$ recorded significantly $(\mathrm{p}<0.05)$ different mean DMC count of $8.35 \log _{10}$ cells/g, $8.56 \log _{10}$ cells/ $\mathrm{g}$ and $8.70 \log _{10}$ cells/g, respectively.

L. acidophilus inoculated samples recorded $7.85 \log _{10}$ cells/g, $8.07 \log _{10}$ cells/g and 8.28 $\log _{10}$ cells/g (Table 5) when added at the rate 
Table 4. Effect of inulin on direct microscopic clump count $\left(\log _{10}\right.$ cells/g) of L. acidophilus and L. casei

\begin{tabular}{|c|c|c|c|c|c|c|}
\hline \multirow[t]{2}{*}{$\begin{array}{l}\% \text { Culture } \\
\text { addition }\end{array}$} & & \multicolumn{3}{|c|}{$\begin{array}{l}\text { Direct microscopic clump count }\left(\log _{10} \text { cells/g) }\right. \\
\text { Inulin } \\
\end{array}$} & \multirow{2}{*}{$\begin{array}{l}\text { Statistical } \\
\text { mean }\end{array}$} & \multirow{2}{*}{$\begin{array}{l}\text { Statistical } \\
\text { mean }\end{array}$} \\
\hline & & $1 \%$ & $2 \%$ & $3 \%$ & & \\
\hline \multirow[t]{3}{*}{ L. acidophilus } & 3 & $7.70 \pm 0.02$ aA & $7.83 \pm 0.03^{\mathrm{aA}}$ & $7.86 \pm 0.05^{\mathrm{aA}}$ & $7.81 \pm 0.15^{\mathrm{a}}$ & \multirow{3}{*}{$8.04 \pm 0.26^{\mathrm{a}}$} \\
\hline & 4 & $7.84 \pm 0.04$ abA & $7.98 \pm 0.04^{\mathrm{abAB}}$ & $8.35 \pm 0.04^{\mathrm{bB}}$ & $8.05 \pm 0.23^{b}$ & \\
\hline & 5 & $8.11 \pm 0.03^{\mathrm{bA}}$ & $8.35 \pm 0.02^{\mathrm{bAB}}$ & $8.44 \pm 0.05^{\mathrm{bB}}$ & $8.30 \pm 0.15^{\mathrm{c}}$ & \\
\hline \multirow{3}{*}{ L. casei } & 3 & $8.61 \pm 0.04^{\mathrm{cA}}$ & $8.97 \pm 0.03^{\mathrm{cB}}$ & $9.10 \pm 0.03^{\mathrm{cB}}$ & $8.89 \pm 0.22^{\mathrm{d}}$ & \multirow{3}{*}{$8.95 \pm 0.21^{\mathrm{b}}$} \\
\hline & 4 & $8.69 \pm 0.06^{\mathrm{cA}}$ & $9.09 \pm 0.04^{\mathrm{cB}}$ & $9.14 \pm 0.05^{\mathrm{cB}}$ & $8.97 \pm 0.21^{\mathrm{e}}$ & \\
\hline & 5 & $8.73 \pm 0.05^{\mathrm{cA}}$ & $9.11 \pm 0.05^{\mathrm{cB}}$ & $9.16 \pm 0.04^{\mathrm{cB}}$ & $9.00 \pm 0.20^{\mathrm{e}}$ & \\
\hline Statistical mean & & $8.28 \pm 0.42^{\mathrm{A}}$ & $8.55 \pm 0.54^{\mathrm{B}}$ & $8.67 \pm 0.50^{\mathrm{C}}$ & & \\
\hline
\end{tabular}

* $\mathrm{n}=3$; Mean \pm SD; Values with different superscripts (abcde) within a column are significantly $(\mathrm{p}<0.05)$ different; Values with different superscripts $(A B C)$ within a row are significantly $(\mathrm{p}<0.05)$ different

Table 5. Effect ofIsomalto-oligosaccharides on direct microscopic clump count $\left(\log _{10}\right.$ cells/g) of L. acidophilus and L.casei

\begin{tabular}{|c|c|c|c|c|c|c|}
\hline \multirow{2}{*}{\multicolumn{2}{|c|}{$\%$ Culture addition }} & \multicolumn{3}{|c|}{$\begin{array}{c}\text { Direct microscopic clump count } \\
\left(\log _{10} \text { cells/g) }\right.\end{array}$} & \multirow{2}{*}{$\begin{array}{c}\text { Statistical } \\
\text { mean } \\
\text { (within } \\
\text { culture) }\end{array}$} & \multirow{2}{*}{$\begin{array}{c}\text { Statistical } \\
\text { mean } \\
\text { (between } \\
\text { culture) }\end{array}$} \\
\hline & & $1 \%$ & $2 \%$ & $3 \%$ & & \\
\hline \multirow[t]{3}{*}{ L. acidophilus } & 3 & $7.73 \pm 0.03$ aA & $7.88 \pm 0.05^{\mathrm{aA}}$ & $7.97 \pm 0.04^{\mathrm{aA}}$ & $7.85 \pm 0.10^{\mathrm{a}}$ & \multirow{3}{*}{$8.07 \pm 0.22^{\mathrm{a}}$} \\
\hline & 4 & $7.89 \pm 0.05^{\mathrm{abA}}$ & $8.01 \pm 0.03^{\mathrm{aAB}}$ & $8.31 \pm 0.03^{\mathrm{aB}}$ & $8.07 \pm 0.19^{\mathrm{b}}$ & \\
\hline & 5 & $8.11 \pm 0.04^{\mathrm{bA}}$ & $8.32 \pm 0.05^{\mathrm{aA}}$ & $8.39 \pm 0.04^{\mathrm{aA}}$ & $8.28 \pm 0.12^{\mathrm{c}}$ & \\
\hline \multirow[t]{3}{*}{ L.casei } & 3 & $8.69 \pm 0.03^{\mathrm{cA}}$ & $9.01 \pm 0.04^{\mathrm{bAB}}$ & $9.16 \pm 0.05^{\mathrm{bB}}$ & $8.95 \pm 0.21^{\mathrm{d}}$ & \multirow{3}{*}{$9.01 \pm 0.18^{b}$} \\
\hline & 4 & $8.80 \pm 0.02^{\mathrm{cA}}$ & $9.10 \pm 0.04^{\mathrm{bAB}}$ & $9.18 \pm 0.02^{\mathrm{bB}}$ & $9.03 \pm 0.17^{\mathrm{de}}$ & \\
\hline & 5 & $8.86 \pm 0.04^{\mathrm{cA}}$ & $9.11 \pm 0.05^{\mathrm{bA}}$ & $9.20 \pm 0.05^{\mathrm{bA}}$ & $9.06 \pm 0.15^{\mathrm{e}}$ & \\
\hline Statistical $\mathrm{m}$ & & $8.35 \pm 0.46^{\mathrm{A}}$ & $8.56 \pm 0.53^{\mathrm{B}}$ & $8.70 \pm 0.51^{\mathrm{C}}$ & & \\
\hline
\end{tabular}

$*_{\mathrm{n}}=3$; Mean $\pm \mathrm{SD}$; Values with different superscripts (abcde) within a column are significantly $(\mathrm{p}<0.05)$ different; Values with different superscripts $(A B C)$ within a row are significantly $(\mathrm{p}<0.05)$ different

of 3,4 and $5 \%$, respectively which was statistically significant $(\mathrm{p}<0.05)$ at all levels. In case of $L$. casei, the sample added with $3 \%$ culture recorded significantly $(\mathrm{p}<0.05)$ lower DMC count $\left(8.95 \log _{10}\right.$ cells/g) as compared to the samples inoculated with $4 \%\left(9.03 \log _{10}\right.$ cells/ g) and $5 \%\left(9.06 \log _{10}\right.$ cells/g) of the L. casei culture.

The result indicates that supplementation of milk with prebiotics significantly $(\mathrm{p}<0.05)$ increased the acidification rate and reduced the fermentation time. Among the selected prebiotics, FOS significantly $(\mathrm{p}<0.05)$ improved the activity of probiotic L. acidophilus and L. casei strains, followed by inulin and IMO. However, non-significant difference between inulin and IMO was noticed. The milk supplemented with 4\% FOS and inoculated with L. casei recorded highest DMC count compared to all the other combinations studied.

\section{DISCUSSION}

Addition of prebiotics namely FOS, inulin and IMO at the rate of $2 \%$ resulted in significant $(\mathrm{p}<0.05)$ decrease in $\mathrm{pH}$ of cultured milk at a faster rate as compared to control samples. Skim 
milk sample added with FOS and inoculated with $L$. acidophilus at $4 \%$ level recorded very low $\mathrm{pH}$ of 4.35 by the end of incubation time of $6 \mathrm{~h}$, followed by inulin $(\mathrm{pH} 4.55)$ and IMO ( $\mathrm{pH} 4.56)$.

The added prebiotics significantly improved the culture activity and thereby increased the rate of acidification. Among the probiotic cultures used, L. acidophilus performed better as compared to L. casei. Amongst prebiotics, FOS influenced the acidification rate more than inulin and IMO. The high acidification rate of L. acidophilus compared to L. casei could be attributed to their ability to produce high lactic acid (Yoon et al., 2005). The better performance of $L$. acidophilus over L. casei and influence of prebiotics on acidification rate is consistent with the observations of Oliveira et al. (2013), who reported that FOS and inulin significantly increase the acidification rate and decrease the fermentation time as compared to the samples without prebiotics in low fat milk. Similar results were also observed by Rodrigues et al. (2011) when L. casei-01, L. acidophilus La-5 and B. lactis B94 strains were added with FOS : inulin (50:50). The lower degree of polymerization (5-8) in case of FOS as compared to inulin $(\sim 25)$ renders FOS to be hydrolysed quicker by microbes and grow faster in presence of FOS (Angus et al., 2005). Olson and Aryana (2012) also observed that inulin added at $1 \%$ and $3 \%$ levels to skim milk and inoculated with $L$. acidophilus exhibited faster development of $\mathrm{pH}$ during incubation as compared to control samples.

Similar trend was observed in the present study for development of acidity in skim milk samples added with selected prebiotics and probiotics. The performance of L. acidophilus and FOS combination was found to be significantly better in development of acidity as compared to all other combination of prebiotics and probiotics tried. This could be attributed to the high acid tolerance and faster lactic acid production ability of $L$. acidophilus as compared to L. casei (Yoon et al., 2005). Nonsignificant difference was noticed between the effect of inulin and IMO on acid production by both the probiotics.

Effect of prebiotics on direct microscopic clump count (DMCC) of $L$. acidophilus and L. casei: FOS and probiotic cultures, individually and in combination significantly $(p<0.05)$ influenced the DMC count of the fermented milk. Increasing the rate of addition of FOS and probiotic culture increased the DMC count of the fermented milk. The DMC count of $L$. case $i$ was significantly $(\mathrm{p}<0.05)$ higher as compared to $L$. acidophilus. The results are in agreement with the observations of Oliveira et al. (2013) who observed significant influence of $4 \%$ FOS in low fat milk on the growth of L. acidophilus $(7.66 \log \mathrm{cfu} / \mathrm{mL})$ as compared to control sample $(7.35 \log \mathrm{cfu} / \mathrm{mL})$. Moreno et al. (2006) reported higher viable cells of L. casei $(9.01 \log \mathrm{cfu} / \mathrm{mL})$ in fermented milk as compared to L. acidophilus $(8.36 \log \mathrm{cfu} / \mathrm{mL}$ ) indicating better growth, multiplication and survivability of $L$. casei in fermented milks as compared to L. acidophilus.

Increasing the level of inulin addition significantly $(\mathrm{p}<0.05)$ increased the DMC count of fermented milk. Similarly, increased rate of addition of culture also showed significant $(\mathrm{p}<0.05)$ increase in the DMC count of L. acidophilus and L. casei. Oliveira et al. (2011) noted that the inulin supplementation in skim milk considerably increased the growth and sustainability of Lactobacillus acidophilus, Lactobacillus rhamnosus and Bifidobacterium lactis in non-fat fermented milk. Inulin promoted the growth and antibacterial activity of L. paracasei TD3 (Mahboubi and Kazempour, 2016). Inulin added at the rate of $1 \%$ and $3 \%$ to skim milk and inoculated with L. acidophilus exhibited increased growth and faster development of $\mathrm{pH}$ during incubation as compared to control samples (Olson and Aryana, 2012). Bedani et al. (2013) reported that addition of inulin at $3 \%$ level to soy milk increased the growth and survivability of L. acidophilus. Similarly, it has been reported by Akalin and Erişir (2008) that the viable 
counts of L. acidophilus La-5 and B. animalis Bb-12 significantly $(\mathrm{P}<0.05)$ increased in the probiotic ice cream mix added with oligofructose. Inulin added at the rate of $4 \%$ to ice cream mix also improved the viability of $L$. acidophilus $\mathrm{La}-5$ and $B$. animalis $\mathrm{Bb}-12$.

Addition of IMO to the milk increased the DMC count of L. acidophilus and L. casei. Among the prebiotics, FOS stands out to be the best prebiotic, which significantly $(\mathrm{p}<0.05)$ increased the total viable probiotic count as compared to inulin and IMO. Oliveira et al. (2013) demonstrated that the low-fat milk supplemented with $4 \%$ FOS exhibited highest acidification rate 23.17 (10-3 $\mathrm{pH}$ units/min), decreased fermentation time $(7.44 \mathrm{~h})$ and high viable cell count as compared to $4 \%$ inulin supplemented sample. Considering the significantly $(\mathrm{p}<0.05)$ higher DMC count of $L$. casei as compared to L. acidophilus in the skim milk, inoculation with $L$. casei at $4 \%$ level was recommended for further optimization of product parameters.

The results clearly indicated that, the addition of prebiotics viz. FOS, inulin and IMO significantly $(p<0.05)$ improved the culture activity and thereby, increased the rate of acidification as compared to control. Among the probiotic cultures used, L. acidophilus

\section{REFERENCES}

Akalin AS and Erişir D, 2008. Effects of inulin and oligofructose on the rheological characteristics and probiotic culture survival in low-fat probiotic cream. J Food Sci, 73(4): M184M188, doi: 10.1111/j.1750-3841. 2008.00728.x

Angus F, Smart S and Shortt C, 2005. Prebiotic ingredients with emphasis on galacto-oligosaccharides and fructo-oligosaccharides. In: Tamime AY (ed.) Probiotic Dairy Products. Blackwell Publishing, Marcel Dekker, Oxford, pp 120-137

AOAC, 1995. Official methods of analysis of AOAC international, $18^{\text {th }}$ ed. method 947.05. Association of Official Analytical Chemists, Arlington, VA, USA

Bedani R, Rossi EA and Isaysaad SM, 2013. Impact of inulin and okara on Lactobacillus acidophilus La5 and Bifidobacterium animalis Bb-12 viability in a fermented soy product and probiotic survival under in vitro simulated gastrointestinal performed better than L. casei in terms of acid production. Addition of prebiotics namely FOS, inulin and IMO (at the rate of $2 \%$ in each case), resulted in a significant decrease in $\mathrm{pH}$ at a faster rate as compared to control samples. The performance of $L$. acidophilus and FOS combination was found to be significantly $(p<0.05)$ better for development of acidity as compared to all other combinations of prebiotics and probiotics tried. Addition of FOS at the rate of 3\% recorded the highest mean DMC count of $8.84 \log _{10}$ cells/g and the L. casei added at the rate of $5 \%$ recorded significantly $(\mathrm{p}<0.05)$ higher DMC count $\left(9.14 \log _{10}\right.$ cells/g) as compared to all the other combinations tried within and between the strains.

Conflict of interest: Authors have no conflict of interest in this study.

Author's contribution: JHM: Conceived the idea and guided the technical program; DHC: Carried out the experiments and wrote the mauscript; JRK: Supervised the work and edited the manuscript.

\section{ACKNOWLEDGMENT}

All the authors extend their sincere thank to the authority of the National Dairy Research Institute for funding this research work.

conditions. Food Microbiol, 34(2): 382-389, doi: 10.1016/j.fm.2013.01.012

Canbulat Z and Ozcan T, 2015. Effects of short-chain and long-chain inulin on the quality of probiotic yogurt containing Lactobacillus rhamnosus. J Food Process Preserv, 39(6): 1251 1260, doi: 10.1111/jfpp. 12343

Harrigan W, 1998. Laboratory methods in food and dairy microbiology, $3^{\text {rd }}$ edition, Department of Food Science, Reading University, Reading Academy Press Inc. (London) ltd. UK

Ibrahim OO, 2018. Functional oligosaccharides: chemicals structure, manufacturing, health benefits, applications and regulations. J Food Chem Nanotechnol, 4(4): 65-76, doi: 10.17756/ jfcn.2018-060

Mahboubi M and Kazempour N, 2016. The effects of inulin on characteristics of Lactobacillus 
paracasei TD3 (IBRC-M 10784) as probiotic bacteria in vitro. Arch Iran Med, 19(2): 92-95

Moreno Y, Collado MC, Ferrús MA, Cobo JM, Hernández E et al., 2006. Viability assessment of lactic acid bacteria in commercial dairy products stored at $4^{\circ} \mathrm{C}$ using Live/Dead BacLight TM staining and conventional plate counts. Int $\mathrm{J}$ Food Sci Technol, 41(3): 275-280, doi: 10.1111/j.13652621.2005.01060.x

Oliveira RP, Perego P, de liveira MND and Converti A, 2011. Effect of inulin as prebiotic and synbiotic interactions between probiotics to improve fermented milk firmness. J Food Eng, 107(1): 3640, doi: 10.1016/j.jfoodeng.2011.06.005

Oliveira RPS, Casazza AA, Baharaliakbarian B, Perego P, Converti A et al., 2013. Influence of fructo-oligosaccharides on the fermentation profile and viable counts in a symbiotic low fat milk. Braz J Microbiol, 44(2): 431-434, doi: 10.1590/S 1517-83822013000200014

Olson DW and Aryana KJ, 2012. Effect of prebiotics on Lactobacillus acidophilus growth and resulting $\mathrm{pH}$ changes in skim milk and a model peptone system. J Microb BiochemTechnol, 4(5): 121-125
Parvez S, Malik KA, Kang SA and Kim HY, 2006. Probiotics and their fermented food products are beneficial for health. J Appl Microbiol, 100: 11711185, doi: 10.1111/j.1365-2672.2006.02963.x

Roberfroid M, Gibson GR, Hoyles L, McCartney AL, Rastall R et al., 2010. Prebiotic effects: metabolic and health benefits. Br J Nutr, 104(S2): S1-S63, doi: $10.1017 /$ S0007114510003363

Rodrigues D, Rocha-Santos TAP, Pereira CI, Gomes AM, Malcata FX et al., 2011. The potential effect of FOS and inulin upon probiotic bacterium performance in curdled milk matrices. LWT - Food Sci Technol, 44(1): 100-108, doi: 10.1016/ j.lwt.2010.05.021

Salminen SJ, Gueimonde M and Isolauri E, 2005. Probiotics that modify disease risk. J Nutri, 135(5): 1294-1298, doi: 10.1093/jn/135.5.1294

Shah NP, 2007. Functional cultures and health benefits. Int Dairy J, 17(11): 1262-1277, doi: 10.1016/ j.idairyj.2007.01.014

Yoon KY, Woodams EE and Hang YD, 2005. Fermentation of beet juice by beneficial lactic acid bacteria. LWT Food Sci Technol, 38(1): 73-75, doi:10.1016/j.lwt.2004.04.008 